\title{
To Solve the Problem of Improving Level of Developing a Pedagogical Consciousness in a Future Math Teacher
}

\author{
Bobovsky Roman \\ ORCID ID: https://orcid.org/0000-0003-0172-6404 \\ Lecturer \\ Pereyaslav-Khmelnytsky State Pedagogical University named after \\ Hryhoriy Skovoroda (Ukraine, Pereyaslav-Khmelnytsky)
}

\begin{abstract}
The article deals with the main approaches to the pedagogical conditions definition for forming pedagogical consciousness in the future mathematics teachers. Given some views of the publications, which examined the issue of pedagogical conditions (O. Kachalov, K. Kostyuchenko, V. Manko, L. Maksymchuk, E. Yakovlev, and others) are considered; motivation for educational activities (S. Rubinstein, V. Sukhomlinsky, P. Yakobson, etc.); importance and stimulation of students' research activities (V. Belyaev, S. Goncharenko, Z. Demchenko, V. Kremen, etc.). The conditions such as motivation increase for studying and the interest in pedagogical activities are presents; the formation in the professional training process subjective position of the students is described; an active involvement of the future math teachers in the process of scientific research activities is substantiated. In the case of their systematic, integrated implementation in the process of educationalprofessional training future mathematics teachers they will provide the qualitative increase in the level of stidents' pedagogical consciousness development.
\end{abstract}

Key words: university, students, pedagogical conditions, pedagogical consciousness; motivation; scientific research activitis of students; math teacher training.

Актуальність дослідження. Науковий аналіз проблеми формування педагогічної свідомості майбутніх учителів математики у процесі підготовки в закладах вищої освіти передбачає визначення низки педагогічних умов, що нададуть змогу ефективно побудувати процес формування зазначеного феномену [18, с. 247].

Підготовка майбутніх учителів математики здійснюється в органічній єдності загального, особливого та індивідуального. Загальне полягає у здобутті вищої освіти і $є$ складовою означеної системи; сутність особливого зумовлюється майбутньою педагогічною діяльністю, необхідністю поєднання фахової, педагогічної та науководослідної діяльності. Індивідуальне означає залежність підготовки від індивідуальних особливостей студента, його здібностей, інтересів, рівня знань та ін.

Аналіз результатів, одержаних на констатувальному етапі дослідження, засвідчив перевагу низького та середнього рівня сформованості педагогічної свідомості майбутніх вчителів математики, що підтверджує необхідність обгрунтування 
педагогічних умов формування педагогічної свідомості та їх експериментальної перевірки [17].

Актуальними для дослідження є праці, які розглядали питання про педагогічні

умови (О. Качалов, К. Костюченко, В. Манько, Л. Максимчук, С. Яковлев та ін.); мотивацію навчальної діяльності (С. Рубінштейн, В. Сухомлинський, П. Якобсон, та ін.); важливість та активізацію науково-дослідної діяльності студентів (В. Бєляєв, С. Гончаренко, 3. Демченко, В. Кремень, С. Кушнірук, Л. Петько, Г. Турчинова та ін.).

Виклад основного матеріалу. Питання про педагогічні умови розглядається у роботах значної кількості науковців. Поняття «педагогічні умови» дослідники використовують у значенні компонента освітнього процесу вищої школи, який забезпечує підвищення його результативності [8, с. 25].

У контексті нашого дослідження ми визначаємо педагогічні умови як внутрішні та зовнішні чинники, які сприяють формуванню нових знань, умінь, навичок, компетенцій або компетентностей. При цьому важливим для нас стало твердження Є. Яковлева про те, що об'єкт може успішно функціонувати лише при визначенні певного комплексу умов, оскільки випадкові умови не можуть розв'язати задачу ефективно [16]. Тому ми поставили завдання визначити комплекс організаційнопедагогічних умов, які забезпечать формування у майбутніх учителів математики педагогічної свідомості.

У результаті проведеної аналітичної роботи нами були виділені такі педагогічні умови формування педагогічної свідомості майбутніх учителів математики: підвищення мотивації до навчання та інтересу до педагогічної діяльності у майбутніх учителів математики; формування суб'єктної позиції студентів у процесі професійної підготовки; активне залучення майбутніх учителів математики до науково-дослідницької роботи.

Перейдемо до розкриття сутності згаданих педагогічних умов. Відомо, тобто мотивація в контексті нашого дослідження є стимулюванням бажання до отримання нових знань, умінь та навичок, а також досвіду педагогічної діяльності. П. Якобсон визначає позитивну мотивацію навчання як таку, яка обумовлюється не лише мотивами учбової діяльності, але й життєвими перспективами [15]. Відповідно позитивна мотивація навчання має дуальний характер: індивідуальний та соціальний. 
Зазначимо, що 3 психологічної і педагогічної точки зору важливою $є$ та індивідуальна мотивація, яка грунтується на пізнавальних потребах i iнтересах студентів, на прийнятті ними пізнавальної цінності навчальної діяльності. Л. Божович, А. Маркова, Є. Ільїн та ін. виділяють, перш за все, внутрішню і зовнішню мотивацію. Основу внутрішньої мотивації складають мотиви, безпосередньо пов’язані з навчальною діяльністю (пізнавальні мотиви), а зовнішньої - мотиви, опосередковані зовнішніми щодо навчальної діяльності стимулами (соціальні мотиви) [19; 20; 21].

В. Сухомлинський вказував на зв’язок праці й знань, який полягає у тому, що праця приносить радість, насичує духовне життя тому, що вона- творчість, у ній розкриваються здібності, обдарування, талант - завдяки цьому утверджується почуття людської гідності. Якщо вихователеві вдається досягнути того, що праця вже в шкільні роки стає частиною духовного життя, відбувається винятково важливе явище: трудова творчість пробуджує нові інтелектуальні інтереси, людині хочеться більше знати для того, щоб глибше проникнути в таємниці праці [13, с. 81].

С. Рубінштейн зазначав, що для того, щоб учень по-справжньому включився в роботу, потрібно зробити так, щоб поставлені під час навчальної діяльності завдання він не тільки зрозумів, але й внутрішньо прийняв, тобто щоб вони стали значимими для нього, знайшли відгук і опорну точку в його переживанні. Причому, рівень свідомості, на думку вченого, суттєво визначається тим, наскільки особистісно значимим для учня виявляється те, що об’ єктивно, суспільно значиме [12, с. 500].

Як бачимо, вчені єдині в тому, що мотивація до навчання, інтерес до навчальнопізнавальної діяльності виступають тією рушійною силою, яка обумовлює продуктивність навчального процесу. Окрім того, у сучасному освітньому процесі першочергового значення набуває не так надання предметних знань, обсяг яких постійно росте, а формування особистості як активного діяча, що має відповідну структуру потребнісно-мотиваційної сфери.

Отже, підвищення мотивації до навчання та інтересу до педагогічної діяльності передбачає формування позитивно-ціннісного ставлення та стійкого інтересу до навчальної дисципліни і педагогічної діяльності, до професії вчителя; бажання здійснювати науковий пошук; прагнення до самовизначення, самореалізації, 
самовдосконалення; впевненості у власній психолого-педагогічній готовності до виконання педагогічної діяльності.

М. Левіна, обрунтовуючи сутність діяльнісного підходу як методологічного принципу управління освітнім процесом студентів, який визначає технології навчання, структуру і функціональні взаємини між суб'єктами освітнього процесу, комунікативні діяльнісні зв'язки між викладачем та студентами, синергетичну систему навчання, яка має тенденцію до саморозвитку, стверджує, що концептуальною основою діяльнісного підходу є ідея інтеріоризації взаємодії особистості з освітнім середовищем [7].

Продуктом професійного навчання при цьому виступає формування особистісного i професійного самовизначення. Засобом же досягнення такої мети науковець називає освітні технології дидактичного управління, спрямовані на засвоєння змісту навчальної інформації та організацію нормативних i творчих способів навчального пізнання. Таким чином, діяльнісний підхід до процесу формування педагогічної самосвідомості майбутніх учителів математики реалізується на основі мети, змісту і технологій управління освітньою підготовкою студентів і спрямовується на управління їхньою навчальною діяльністю.

Відповідно, формування педагогічної свідомості майбутніх учителів математики на основі діяльнісного підходу буде успішним за умови дотримання таких принципів: ціннісної значущості підходу до діяльності та іiі результатів 3 позиції користі та значущості; особистісної орієнтації - спрямування діяльності на задоволення особистих цілей; моральної значущості - спрямування діяльності відповідно до мотивів, цінностей та настанов особистості.

Для реалізації означених вимог потрібна така організація навчального процесу, за якої формування знань, вмінь та навичок підпорядковується розвитку складної системи професійної діяльності. Досягнення такого результату вимагає зміни форм та методів організації професійного навчання: замість оволодіння алгоритмами професійної діяльності, які були сталими упродовж багатьох десятиріч, необхідно навчати студентство роботі в швидкозмінних умовах.

У контексті вище сказаного у розрізі проблематики нашого дослідження особливого значення набуває формування суб'єктної позиції студентів у процесі професійної підготовки. А. Осницький, досліджуючи проблеми суб’єктної активності 
вказував, що суб'єктність - це системна якість особистості, що оволодіває різнобічними новими видами і формами діяльності і соціальних відносин, індивідуальним комплексом особистісно-психологічних функцій, котрі визначають і відображають результативність здійснюваної ним діяльності, а також детермінують його сутнісну, інтегральну характеристику - загальну здатність до усвідомленого, самостійного, цілеспрямованого перетворення вихідних знань у соціально значущі якості [10, с. 12]. Суб'єктність проявляється в навчально-пізнавальній діяльності, спілкуванні, самопізнанні і при цьому характеризує досягнутий рівень продуктивності і успішності в здійснюваних видах діяльності, що відображає можливості студента щодо досягнення поставлених цілей i розв'язування конкретних завдань. Відповідно формування педагогічної свідомості вимагає від майбутнього педагога внутрішньої впорядкованості та структурованості смислів, цінностей, здатності до саморегуляції власних дій, ставить особливі вимоги до його професійної позиції і, власне, виявляється через цю позицію.

За необхідне вважаємо зауважимо, що в сучасних умовах розвитку педагогічної науки суб'єктність цілком правомірно можна розглядати як методологічний принцип у педагогічних дослідженнях, присвячених проблемам розвитку активної позиції особистості щодо здійснення нею професійної діяльності та інших форм життєдіяльності. При цьому суб'єкт виступає як активна, діюча, відповідальна за результати своєї праці особистість, здатна до самокритики, самоаналізу, самооцінки.

Крім того, що особливо важливо у контексті проблематики нашого дослідження, суб'єктність визначає особливу форму самоконтролю в різних ситуаціях професійної діяльності. А значить, ми можемо припустити, що вона детермінує і процес формування педагогічної свідомості майбутнього вчителя, який також обумовлюється механізмами самоконтролю та саморегуляції. Саме сформована суб’єктна позиція свідчитиме про результат особистісно-професійного становлення, адже є пов'язаною із самосвідомістю майбутнього фахівця, з усвідомленням ним цілей і завдань професійної діяльності, 3 системою його ціннісних орієнтацій та смислів, з розвиненою здатністю до рефлексії та творчого саморозвитку.

При визначенні наступної педагогічної умови формування педагогічної свідомості майбутніх учителів математики було враховано, що здійснення професійної 
діяльності на рівні, що відповідає сучасним вимогам, під силу педагогу, який постійно вдосконалює свою професійну компетентність, який готовий до здійснення не тільки викладацької, а й науково-дослідної діяльності.

Розв'язання цього завдання можливе, на нашу думку, за умови зміни характеру навчальної діяльності майбутніх учителів математики, за умови переходу зі статусу репродуктивного споживача знань у позицію їх активного творення. Тому важливо, як наголошує академік В. Кремень, «забезпечити високу функціональність людини в умовах, коли зміна ідей, знань і технологій відбувається набагато швидше, ніж зміна покоління людей. Також потрібно віднайти раціональні схеми співвідношення між лавиноподібним розвитком знань, високих технологій і людською здатністю їх творчо засвоїти» [6].

У зв’язку з вищезазначеним, науково-дослідницька діяльність студентів володіє чи не найбільшим потенціалом професійного самовдосконалення особистості майбутнього педагога. Отже, наступною організаційно-педагогічною умовою розвитку педагогічної свідомості майбутніх учителів математики визначено активне залучення до науково-дослідницької роботи.

Як зазначає Ю. Бєляєв, науково-дослідна діяльність студентів - це діяльність, пов’язана з пошуком відповіді на творчу, дослідницьку задачу із заздалегідь невідомим рішенням. Вона включає у себе наступні етапи: постановку проблеми; вивчення теорії, що присвячена означеній проблематиці; добір методик дослідження і практичне оволодіння ними; пошук необхідного матеріалу, його аналіз та узагальнення; власні висновки [1, с. 190].

В «Українському педагогічному словнику» розглядається сутність дослідницького методу, що полягає в залученні учнів до самостійних спостережень, на основі яких установлюються зв'язки предметів і явищ дійсності, пізнаються закономірності, формулюються висновки. С. Гончаренко наголошує, що дослідницька діяльність сприяє вихованню в учнів допитливості, ініціативності, прагнення до самостійного пошуку, розвиває активність їхніх розумових процесів [2].

Аналіз науково-методичної літератури та власний педагогічний досвід дають підстави стверджувати, що науково-дослідницька діяльність студентів є засобом їхньої 
професійної підготовки, адже має всі ознаки навчально-пізнавальної діяльності і водночас творчої, актуалізує творчі можливості особистості $[11 ; 14 ; 22]$.

За необхідне вважаємо зауважити, що, на нашу думку, науково-дослідницька діяльність студентів дає їм можливість відчути себе частиною світової культури (науки), адже за своєю суттю вона $є$ своєрідним інститутом соціалізації молоді і повинна керуватися ії запитами, ціннісними орієнтаціями, потребами творчого розвитку.

Ми розділяємо думку 3. Демченко, який наголошує, що науково-дослідницька діяльність студентів вузу виробляє у них психологічну установку на самостійне потребнісно-мотиваційне поповнення знань і розвиток вміння орієнтуватися в потоці наукової інформації при розв'язанні певних завдань [3, с. 100]. При цьому переконані, що в організації науково-дослідницької діяльності особливу роль відіграє освітнє середовище [22], в якому студенти осягають основи не тільки самої діяльності, але і комунікативної культури, культури міжособистісного спілкування, в якому створюються умови для самоактуалізації і реалізації творчого потенціалу.

Висновки. Таким чином, науково-дослідницька діяльність студентів впливає на побудову їхніх індивідуальних освітніх траєкторій, маршрути подальшого особистісного i професійного самовизначення i самовдосконалення. Через що, реалізація виокремлених організаційно-педагогічних умов у процесі професійної підготовки студентів педагогічного вищого навчального закладу сприятиме, на нашу думку, позитивній динаміці формування педагогічної свідомості майбутніх учителів математики.

\section{References}

1. Bieliaiev Yu.I. Naukovo-doslidna diialnist studentiv u strukturi roboty universytetu [Research activities of students in the structure of the university work] // Pedahohichnyi almanakh. - 2010. - Vol. 6. - P. 188-191.

2. Honcharenko S. Ukrainskyi pedahohichnyi slovnyk [Ukrainian Pedagogical Dictionary]. - Kyiv: Lybid, 1997. - P. 206.

3. Demchenko Z.A. Zhyznennye stratehyy studentov v nauchno- issledovatelskoi deiatelnosty kak pedahohycheskaia problema vysshei professyonalnoi shkoly $v$ ye alternatyvnoe reshenye [Students' life strategies in research as a pedagogical problem of higher vocational school and its alternative solution] // Ystorycheskaia y sotsyalno-obrazovatelnaia mysl. 2012. Vol. 3. P. 98-102.

4. Kachalov A.V. Pedahohycheskye uslovyia formyrovanyia tvorcheskoi samostoiatelnosty studentov pedvuza [Pedagogical conditions of formation of creative independence of students of the pedbuza] // Yzvestyia Uralskoho hosudarstvennoho unyversyteta. - Problemy obrazovanyia, nauky y kultury. 2009. No. 12 (62). P. 212-217. 
5. Kostiuchenko K.Ie. Pedahohichni umovy formuvannia ratsionalno krytychnoho myslennia $u$ maibutnikh uchyteliv $u$ protsesi vyvchennia psykholoho-pedahohichnykh dystsyplin [Pedagogical conditions for the formation of rational-critical thinking in future teachers in the process of studying psychological and pedagogical disciplines]: avtoref. dys. kand. ped. nauk: 13.00.04; Kirovohr. derzh. ped. un-t im. V. Vynnychenka. Kirovohrad, 2011. 20 p.

6. Kremen V.H. Filosofiia liudynotsentryzmu $v$ osvitnomu prostori [Philosophy of human-centeredness in the educational space]. Kyiv: Tov. «Znannia», 2011.530 p.

7. Levyna M.M. Deiatelnostnyi podkhod kak metodolohychekyi pryntsyp upravlenyia obrazovatelnym protsessom studentov [Activity approach as a methodological principle of managing the student's educational process] // Pedahohycheskoe obrazovanye i nauka. 2009. Vol. 2.

8. Maksymchuk L.V. Pedahohichni umovy zastosuvannia interaktyvnykh tekhnolohii u pidhotovtsi maibutnikh ekonomistiv-mizhnarodnykiv [Pedagogical conditions of application of interactive technologies in preparation of future economists-internationalists]. Visnyk Natsionalnoi akademii Derzhavnoi prykordonnoi sluzhby Ukrainy. 2012. Vol. 1. P. 23-29.

9. Manko V.M. Dydaktychni umovy formuvannia u studentiv profesiinopiznavalnoho interesu do spetsialnykh dystsyplin [Didactic conditions of formation of students of professional cognitive interest in special disciplines] // Sotsializatsiia osobystosti: zb. nauk. pr. Natsionalnoho ped. un-tu im. M.P. Drahomanova.

Kyiv: Lohos, 2000. Vol. 2. P. 153-161.

10. Osnytskyi A.K. Problemy issledovanyia subyektnoy aktyvnosty [Problems of study of subject activity]. Voprosy psykholohyy. 1996. Vol. 1. P. 5-19.

11. Pet'ko L.V. Napysannja $i$ zahyst referativ inozemnoju movoju za profesijnym sprjamuvannjam - odyn iz shljahiv pidgotovky studentiv do navchannja u magistraturi [Writing and defense of a report in foreign language (in the professional way) as one of the means of students' preparation for teaching in magistracy] / Naukovyj chasopys Nacional'nogo ped. un-tu imeni M.P. Dragomanova. Serija No 5. Pedagogichni nauky: realii' ta perspektyvy. Vol.35: zbirnyk naukovyh prac'. Kyiv : Vyd-vo NPU imeni M.P.Dragomanova, 2012. P. 132138.

12. Rubynshtein L.S. Osnovy obshchei psykholohyy [Fundamentals of general psychology]. SPb.: Pyter, 2000. P. 720.

13. Sukhomlynskyi V.O. Problemy vykhovannia vsebichno rozvynenoi osobystosti [Problems of education of a fully developed personality]. Vybr. tvory: v 5 t. - Kyiv: Rad. shk., 1976. Vol. 1. 654 p.

14. Turchynova H.V. Pidhotovka maibutnikh vchyteliv pryrodnychykh dystsyplin do doslidnytskoi diialnosti u protsesi navchannia inozemnoi movy za fakhom [Future Science teachers training for research activities in the process of foreign language teaching in the professional way]. Topical issues of education: Collective monograph. Pegasus Publishing, Lisbon, Portugal, 2018. 260 p. P. 70-84.

15. Yakobson P.M. Psykholohyia chuvstv y motyvatsyy [Psychology of feelings and motivation]: yzbr. psykhol. tr. - Moskva-Voronezh: Ynt. prakt. psykholohyy; MODEK, 1998. $304 \mathrm{p}$.

16. Yakovlev E.V. Pedahohycheskaia kontseptsyia: metodolohycheskye aspekty postroenyia [Pedagogical Concept: Methodological Aspects of Construction]. Moskva: Humanytar. yzd. tsentr VLADOS, 2006. 239 p. 
17. Bobovsky R.P. Model structural components of pedagogical consciousness formation in future math teacher. Geopolitical processes in the world today: Collection of scientific articles. - «East West» Association for Advanced Studies and Higher Education. Vienna (Austria). 2016. P. 286-289.

18. Bobovsky R.P. Terminological analysis of the concept «pedagogical consciousness» in psychological and pedagogical researches. Science and practice: Collection of scientific articles. - Thorpe Bowker. Melbourne, Australia, 2016. P. 246-267.

19. Kushniruk S. Educational-Methodical Literature as a Resource for the Establishnment and Development of the Conceptual and Terminological System in Ukrainian Didactics (the end of the XVIth century - beginning of the XXIst Century). Intellectual Archive. - Toronto: Shiny Word.Corp. (Canada). 2018. (May/June). Vol. 7. No. 3. PP. 168-181.

20. Kushniruk S.A. Formation of readiness for research activity of students in the process of general-pedagogical preparation. Science and practice: Collection of scientific articles. - Thorpe Bowker. Melbourne, Australia, 2016. - P. 262-267. RSCI: http://elibrary.ru/item.asp?id=28413122

21. Kushniruk S.A. Teaching group activities as an effective form in future competitive teachers training. Actual problems of globalization: Collection of scientific articles. - Midas S.A., Thessaloniki, Greece, 2016. P. 220-223.

URI http://enpuir.npu.edu.ua/handle/123456789/11305,

22. Pet'ko L.V. The formation of professionally oriented foreign language teaching environment for Math students in the conditions of university. Prospects for development of education and science: Collection of scientific articles. - Academic Publishing House of the Agricultural University Plovdiv, Bulgaria, 2016. P. 352-356.

\section{Translation of the Title, Abstract and References to the Author's Language}

\section{УДК 378.011.3-051:51}

\section{Роман Бобовський. До проблеми підвищення рівня розвитку педагогічної свідомості майбутнього вчителя математики}

У статті розглянуто основні підходи до визначення педагогічних умов формування педагогічної свідомості майбутніх вчителів математики. Обгрунтовано умови (підвищення мотивації до навчання та інтересу до педагогічної діяльності; формування суб'єктної позииіі студентів у процесі професійної підготовки; активне залучення майбутніх учителів математики до науково-дослідницької роботи), які, у разі їх систематичного, комплексного впровадження у прочес навчально-професійної підготовки майбутніх учителів математики, забезпечать якісне підвищення рівня розвитку їхньої педагогічної свідомості.

Ключові слова: педагогічні умови; педагогічна свідомість; мотивація; науководослідна робота студентів; підготовка вчителя математики.

\section{Література}

1. Бєляєв Ю.І., Стеценко Н.М. Науково-дослідна діяльність студентів у структурі роботи університету. Педагогічний альманах. 2010. Вип. 6. С. 188-191.

2. Гончаренко С. Український педагогічний словник . Київ: Либідь, 1997. С. 206. 
3. Демченко 3. А. Жизненные стратегии студентов в научно-исследовательской деятельности как педагогическая проблема высшей профессиональной школы и ее альтернативное решение. Историческая и социально-образовательная мысль. 2012. № 3. С. $98-102$.

4. Качалов A.В. Педагогические условия формирования творческой самостоятельности студентов педвуза. Известия Уральского государственного университета. - Проблемы образования, науки и культуры. 2009. № 12 (62). С. 212217.

5. Костюченко К. Є. Педагогічні умови формування раціонально-критичного мислення у майбутніх учителів у процесі вивчення психолого-педагогічних дисциплін: автореф. дис. канд. пед. наук: 13.00 .04 / К.Є. Костюченко; Кіровогр. держ. пед. ун-т ім. В. Винниченка. Кіровоград, 2011.20 с.

6. Кремень В.Г. Філософія людиноцентризму в освітньому просторі. Київ: Тов. «Знання», 2011. С. 530.

7. Левина М.M. Деятельностный подход как методологичекий принцып управления образовательным процессом студентов. Педагогическое образование и наука. 2009. № 2.

8. Максимчук Л.В., Романишина Л.М. Педагогічні умови застосування інтерактивних технологій у підготовці майбутніх економістів-міжнародників. Вісник Національної академії Держсавної прикордонної служби України. 2012. № 1. С. $23-29$.

9. Манько В.М. Дидактичні умови формування у студентів професійнопізнавального інтересу до спеціальних дисциплін. Соиіалізаиія особистості: зб. наук. пр. Національного пед. ун-ту ім. М.П. Драгоманова. Київ: Логос, 2000. Вип. 2. C. $153-161$.

10. Осницкий А.К. Проблемы исследования субъектной активности. Bonpocbl психологии. 1996. № 1. С. 5-19.

11. Петько Л.В. Написання і захист рефератів іноземною мовою за професійним спрямуванням - один із шляхів підготовки студентів до навчання у магістратурі / Л.В. Петько // Науковий часопис Національного педагогічного університету імені М.П. Драгоманова. Серія № 5. Педагогічні науки: реалії та перспективи. - Випуск 35 : зб. наук. праць. - Київ: Вид-во НПУ імені М.П. Драгоманова, 2012. С. 132-138.

12. Рубинштейн Л.С. Основы общей психологии. СПб.: Питер, 2000. 720 с.

13. Сухомлинський В.О. Проблеми виховання всебічно розвиненої особистості. Вибр. твори: в 5 т. Київ: Рад. шк., 1976. Т. 1. С. 654.

14. Турчинова Г.В. Підготовка майбутніх вчителів природничих дисциплін до дослідницької діяльності у процесі навчання іноземної мови за фахом / Г.В. Турчинова // Topical issues of education: Collective monograph. - Pegasus Publishing, Lisbon, Portugal, 2018. -260 p. - P. 70-84.

15. Якобсон П.М.Психология чувств и мотивации: избр. психол. тр. МоскваВоронеж: Инт. практ. психологии; МОДЭК, 1998. С. 304.

16. Яковлев Е.В., Яковлева Н.О. Педагогическая концепция: методологические аспекты построения. Москва: Гуманитар. изд. центр ВЛАДОС, 2006. С. 239.

17. Bobovsky R.P. Model structural components of pedagogical consciousness formation in future math teacher. Geopolitical processes in the world today: Collection of scientific articles. - «East West» Association for Advanced Studies and Higher Education. Vienna (Austria). 2016. P. 286-289. 
18. Bobovsky R.P. Terminological analysis of the concept «pedagogical consciousness» in psychological and pedagogical researches. Science and practice: Collection of scientific articles. - Thorpe Bowker. Melbourne, Australia, 2016. P. 246-267.

19. Kushniruk S. Educational-Methodical Literature as a Resource for the Establishnment and Development of the Conceptual and Terminological System in Ukrainian Didactics (the End of the XVIth century - Beginning of the XXIst Century). Intellectual Archive. - Toronto : Shiny Word.Corp. (Canada). 2018. (May/June). Vol. 7. No. 3. PP. 168181.

20. Kushniruk S.A. Formation of readiness for research activity of students in the process of general-pedagogical preparation. Science and practice: Collection of scientific articles. - Thorpe Bowker. Melbourne, Australia, 2016. - P. 262-267. URL: http://elibrary.ru/item.asp?id=28413122

21. Kushniruk S.A. Teaching group activities as an effective form in future competitive teachers training. Actual problems of globalization: Collection of scientific articles. - Midas S.A., Thessaloniki, Greece, 2016. P. 220-223. URI http://enpuir.npu.edu.ua/handle/123456789/11305 ,

22. Pet'ko L.V. The formation of professionally oriented foreign language teaching environment for Math students in the conditions of university. Prospects for development of education and science: Collection of scientific articles. - Academic Publishing House of the Agricultural University Plovdiv, Bulgaria, 2016. P. 352-356. 